\title{
Implementation Of Police Role In Countermeasures Of Traffic Criminal Acts Of Traffic Violations In Efforts To Establish Police Images As Community Guidelines
}

\begin{abstract}
Riyanto $^{1}$, Umar Ma'ruf ${ }^{2}$ and Sri Kusriyah ${ }^{3}$
Abstract. This study aims to determine the implementation of the role of the police in traffic criminal acts of traffic violations in an effort to build the image of the police as a community protector and inhibiting factors and solutions. The method used is sociological juridical, descriptive analytical research specifications. The data used are primary data and secondary data. Data collection methods are field studies and library studies. The data analysis method uses qualitative analysis. As a knife of analysis, crime prevention theory and law enforcement theory are used. The results showed that the implementation of the role of the police in tackling traffic violations in an effort to build the image of the police as a community protector was carried out through preemptive, preventive and repressive efforts. Pre-emptive efforts are carried out through socialization activities whose main purpose is to instill moral values in society to obey the law. Preventive efforts are carried out through operations or patrols to prevent traffic violations. While repressive efforts carried out through actions in the form of reprimands or tickets to violators. Inhibiting factors in implementing the role of the police in tackling traffic violations in an effort to build an image as a community protector are the lack of professionalism of the traffic police, the legal awareness of the community is still low, and there is a culture of lawlessness from the community.

Keywords: The Role Of The Police; Criminal Acts; Traffic Violations.
\end{abstract}

\section{Introduction}

The deterioration of the image of the National Police in the eyes of the public is an important issue which until now continues to imprison the Indonesian National Police in carrying out its duties and authority as a guardian of public security and order, conducting law enforcement, and providing guidance, protection and creating security, order and the smooth flow of traffic in serving Public. This phenomenon seems to remain an eternal cycle within the Indonesian National Police (Polri), if the

\footnotetext{
${ }^{1}$ Student of Master of Law, Faculty of Law, Sultan Agung Islamic University (UNISSULA) Semarang, email ryanmoza1@gmail.com

${ }^{2}$ Lecturer Faculty of Law, Sultan Agung Islamic University (UNISSULA) Semarang

${ }^{3}$ Lecturer Faculty of Law, Sultan Agung Islamic University (UNISSULA) Semarang
} 
commitment of professionalism, transparency and accountability is not manifested in the attitudes and actions of the police in carrying out daily duties and authority. ${ }^{4}$

The performance of the police has been running as it should according to the legal rules that govern it. There are many police achievements recorded, documented and reported, but they have not been able to defeat the negative image that developed. Often the police institution experiences image degradation caused by one or two persons alone.

The campaign for a good image has been carried out programmatically by police agencies in each region to the center, and vice versa. But it has not been able to fight the negative image that comes to attack massively. Allegedly, this is because police procedures require strict administration and instructions. The structure of leadership and the flow of communication make it such a pattern and climate. ${ }^{5}$

One effort to build the image of the National Police in overcoming traffic violations in Blora Regency is the implementation of the E-Ticket (Electronic Traffic) program issued by the National Police Traffic Police. E-Ticket is a Satlantas program for improving public services and reducing the practice of extortion. Every citizen who commits an offense will be given a ticket from the Blora Traffic Police Precinct and immediately pays the ticket fine at the bank by showing the ticket.

For violators who do not recognize the violation, the person concerned will attend court in court. With the E-Ticket program, It is expected that all personnel of the Blora Police Traffic Unit can carry out their duties as well as possible and are ready to carry out the E-Ticket program so get a positive image and trust from the community. ${ }^{6}$

Based on the description above, the authors are interested in conducting research with the title: "Implementation Of Police Role In Countermeasures Of Traffic Criminal Acts Of Traffic Violations In Efforts To Establish Police Images As Community Guidelines".

Based on the background description described above, the following problems are formulated: How Is The Implementation Of Police Role In Countermeasures Of Traffic Criminal Acts Of Traffic Violations In Efforts To Establish Police Images As Community Guidelines? What Factors Are Obstacles In Implementation Of Police Role In Countermeasures Of Traffic Criminal Acts Of Traffic Violations In Efforts To Establish Police Images As Community Guidelines And What Is The Solution?

\section{Research Methods}

\footnotetext{
4Jaya Suprana, 1995, "Polisi dan Pelayanan Masyarakat", Police National Seminar Paper I, organized by the UNDIP Police Study Center, 1995, p. 1

${ }^{5}$ Abdullah Khusairi, "Membangun Citra Positif Polri (Sebuah Strategi Menguasai Media Massa \& Media Sosial)", Paper in Limited Discussion with the Head of Public Relations of West Sumatra Regional Police, January 2016, (https://www.academia.edu, accessed 20 November 2019)

6 Biar Polisi Lalu Lintas Blora Tak Pungli maka Dikenalkan e-tilang, (https://www.murianews.com, accessed November 20, 2019).
} 
The method used in this research is the sociological juridical approach, namely a method of procedure used to solve research problems by researching secondary data first and then proceeding with conducting research on primary data in the field. ${ }^{7}$ The research specifications are analytical descriptive, while the sources and types of data used are primary data and secondary data. Methods of data collection by field study and literature study. The data analysis method uses qualitative analysis.

\section{Results And Discussion}

\subsection{Implementation Of Police Role In Countermeasures Of Traffic Criminal Acts Of Traffic Violations In Efforts To Establish Police Images As Community Guidelines} Based on the results of research at the Blora Police Station, it is known that the implementation of the role of the police in tackling traffic offenses in an effort to build the image of the police as a community protector is through pre-emptive (deterrence), preventive and repressive measures.

- Pre-emptive effort (deterrence)

Based on the results of interviews with the Blora Headquarters of Saltantas Police, the preemptive efforts undertaken to tackle traffic violations are through Round Explanation (Penling), Extra curricular for safety riding, Police going to school, Police Friends of Children (PSA), and socialization of the dangers of using mobile phones. when driving ${ }^{8}$

- Preventive measures

Preventive efforts undertaken by the Blora Police Traffic Unit are through activities: ${ }^{9}$

- Bus crew and bus inspections at the terminal

The bus and bus crew inspection activities are carried out at the terminal with the relevant agencies.

- Temple obedient operation

Operation Obedient Temple aims to increase public awareness in the fields of security, safety, order and fluency in traffic. The 2019 Temple Compliance Operation prioritizes a measurable and humanist law enforcement process in the form of a ticket to traffic violators. Drivers are also encouraged to give priority to safety when using a vehicle. The appeal is always conveyed at every opportunity such as socialization or raids.

- Zebra operation

The efforts of the Blora Police Satlantas in suppressing the level of traffic violations by zebra operations. The target of Zebra Candi Operation 2019 is a

\footnotetext{
${ }^{7}$ Ronny Hanitijo Soemitro, 1989, Metodologi Penelitian Hukum dan Jurimetri, Ghalia, Jakarta, p.9

${ }^{8}$ The results of an interview with IPDA Panca Driyanto as Head of Unit of the Police Traffic Unit of Blora, 21 February 2020.

${ }^{9}$ Results of Interview with AKP Dodiawan S as Kasatlantas Blora Regional Police, on 18 February 2020.
} 
violation that can lead to fatality of accident victims. This is done to reduce the number of victims and the number of traffic accidents.

- Patrol

Blora Police Satlantas conducts patrol activities every morning, afternoon and night to reduce the level of traffic violations that can trigger traffic accidents. Patrols are usually carried out around Street of Blora-Cepu.

- Repressive measures (repression)

Repressive effort is an effort made after the occurrence of traffic violations with law enforcement as well as the imposition of sentences on the perpetrators of traffic violations. The actions taken by the Blora Police Satlantas officers were to take action in the form of a reprimand and the issuance of a ticket. ${ }^{10}$

- Enforcement with reprimand.

Repression with reprimand is regulated in Article 265 paragraph (3) of Act No. 22 of 2009 On Traffic and Road Transportation which states that to carry out an action in the form of motorized vehicle inspection, the Republic of Indonesia police officers are authorized to take other actions in the form of stopping motorized vehicles, request information from the driver and take other legal actions responsibly.

- Enforcement by giving a ticket

This relates to article 265 paragraph (1) item (a) of Act No. 22 of 2009 On Traffic and Road Transportation which states that the inspection of motorized vehicles on the road which includes checking of driving licenses, letters of motorized vehicle numbers, certificates try motorized vehicles, motorized vehicle number signs, or motorized vehicle signs. Any motorist who violates the above provisions will be dealt with a ticket.

In repressive efforts to tackle traffic violations, the Blora Police Traffic Police Unit acts as an investigator. The Blora Police Satlantas has made every effort to take action against the perpetrators of traffic violations in the form of warnings or tickets. In 2017 there were 80,888 cases of traffic violations that were dealt with by the Blora Police Traffic Unit, while in 2018 traffic violations cases were handled by the Blora Police Traffic Unit as many as 90,782 cases and in 2019 cases of traffic violations acted by the Blora Police Traffic Unit were as many as 48,942 cases.

Based on the results of interviews with KaSatlantas Blora Police, when the operation was carried out especially in the zebra temple operation in 2019, the offenders who were ticketed could be immediately held for trial at the site. In this case acted as the sole judge, Blora Morinda Krisna as District Court Judge. The on-site assembly is to simplify and shorten the time of the community in completing the ticketing process.

${ }^{10}$ Results of an Interview with AKP Dodiawan S, as Kasatlantas Blora Regional Police, on 18 February 2020 
Through these activities, the community can directly hold a hearing and decide directly by the judge regarding the fine. Furthermore, the violators can immediately take confiscated evidence. In the operation, the on-site trial began with a joint operation carried out by Blora Police Officers and the Blora Transportation Office. It also provided a Samsat Blora Around Mobile Car.

In the process of investigating traffic violations (ticketing) is done very easily and simply, besides that there are no known accusation letters and the inspection procedure has been made by the police in the form of a form consisting of 5 parts namely:

- Red form for violators

- blue and green forms for the court

- Yellow form for the police

- White form for prosecutors

With these forms already prepared, if the perpetrators are proven to have committed a traffic violation, the police can immediately request a signature from the violators who have committed the violation and also signed by the investigating officer to be submitted to the court. Investigation of road traffic offenses is not required by the public prosecutor, nor is BAP (Minutes of Examination) required. The ticket from the direct investigator can be considered as a warrant.

The role of the police in overcoming the crime of traffic violations at Blora Police Station in order to build the image of the police as a community protector has been in accordance with crime prevention theory. In the theory of crime prevention it is stated that crime prevention efforts are proactive and reactive activities directed at perpetrators and victims, and in the social and physical environment, which are carried out before or after a crime has been committed through pre-emptive, preventive and repressive measures. ${ }^{11}$

\subsection{Inhibiting Factors in Implementing the Role of the Police in the Prevention of Criminal Acts of Traffic Violations in Efforts to Build an Image as a Community Protector and Its Solution}

The implementation of the role of the police in tackling traffic crime in building an image as a community protector does not always run smoothly. There are several inhibiting factors in its implementation, namely: ${ }^{12}$

- Lack of professionalism in the traffic police

Traffic police in carrying out their duties directly intersect with people who commit violations. Based on the results of an interview with one of the residents, it turns

\footnotetext{
${ }^{11}$ Markas Besar Kepolisian Negara Republik Indonesia, 2005, Perpolisian Masyarakat, Jakarta, p. 2

12 Results of an Interview with AKP Dodiawan S, as Kasatlantas Blora Regional Police, on 18 February 2020
} 
out there are still police officers who still take bribes from motorists when conducting traffic violation operations. One truck driver stated that there were still police officers who wanted to be paid on the spot when they were found not to complete vehicle documents such as late paying taxes or KIR testing. ${ }^{13}$

The attitude of some police officers who are still willing to be paid on the spot in the event of a traffic violation still reflects the bad image of the police. Although not all police officers are willing to be at peace with traffic violators, it is undeniable that such habits still exist and are still ongoing today.

The professionalism of members of the traffic police in carrying out their duties is a very significant problem. The police as a law enforcement officer is one of the keys in realizing good law enforcement and if at that central point has been damaged it is certain that law enforcement in Indonesia will be stagnant.

To overcome this, Blora Regional Police conducts routine activities in the form of recitation of Spiritual and Mental Guidance routinely. In addition, the E-Ticket program is a Satlantas program for improving public services and reducing the practice of extortion. Every citizen who commits an offense will be given a ticket from the Blora Traffic Police Precinct and immediately pays the ticket fine at the bank by showing the ticket. With the E-Ticket program, It is expected that all personnel of the Blora Police Traffic Unit can carry out their duties as well as possible and are ready to carry out the E-Ticket program so get a positive image and trust from the community.

- The level of public awareness is still low

The level of public awareness of Blora Regency is still low in traffic. This can be seen from the many traffic violations that occur such as frequent drivers not paying heed to traffic signs such as running through red lights, not wearing helmets, breaking markers, not having a SIM, or completeness of vehicles that have not been equipped. The Blora community still has the character of underestimating safety and driving safety.

In order to overcome these obstacles, the Blora Police Satlatas ranks continue to socialize the culture of orderly traffic with various socialization and safety riding activities carried out in schools, motorcycle clubs and the general public, holding operations, and enforcement with speeding tickets. Through these activities, it is hoped that the public will become more aware, orderly and obedient, and disciplined in driving and obeying the laws and regulations in traffic. In addition, it is also to increase public awareness and compliance in order to create security in order safety and traffic management (Kamseltibcarlantas).

- Community cultural factors that are not law-abiding

\footnotetext{
${ }^{13}$ Results of an interview with Mr. Rahmat, one of the truck drivers in Blora on February 2, 2020.
} 
The legal culture of the people in the Blora district police jurisdiction is still low. This can be seen from the habit of people who do not heed the traffic rules if there are no police officers on guard on the road. For example, new people will wear helmets when driving if the road is passed there is an officer on guard. Violations of traffic signs often occur and have become a habit such as parking under traffic signs that are forbidden to park in that place, turning the direction is not in accordance with the rules, and stopping in front of the sign prohibiting stop has become a common and frequent activity. done by the community. In addition, the culture of uncomfortable (Pekewuh) that develops in the community influences law enforcement in traffic violations.

To overcome these obstacles, the Blora Police Traffic Unit seeks to instill a culture of orderly traffic through socialization activities to the community.

\section{Closing}

\subsection{Conclusion}

- The implementation of the role of the police in overcoming the crime of traffic violations in an effort to build the image of the police as a community protector is carried out through pre-emptive, preventive and repressive efforts.

- Inhibiting factors in implementing the role of the police in tackling traffic violations in an effort to build an image as a community protector are the lack of professionalism of the traffic police, the legal awareness of the community is still low, and there is a culture of lawlessness from the community. As a solution to overcome these obstacles is the spiritual and mental development (Binrohtal) and the application of E-Ticketing, fostering the community through preemptive, preventive and repressive efforts so that the community is aware of the law, and inculcating a law-abiding culture towards the community through socialization activities.

\subsection{Suggestion}

- For the police, it should improve the professionalism of work so that it can support the implementation of duties as a traffic police.

- For the community, it should take part in supporting the creation of an orderly traffic by complying with the applicable laws and regulations in traffic

\section{References}

\section{Book}


[1] Jaya Suprana, 1995, "Polisi dan Pelayanan Masyarakat", Makalah Seminar Nasional Polisi I, diselenggarakan oleh Pusat Studi Kepolisian UNDIP, 1995.

[2] Markas Besar Kepolisian Negara Republik Indonesia, 2005, Perpolisian Masyarakat, Jakarta.

[3] Ronny Hanitijo Soemitro, 1989, Metodologi Penelitian Hukum dan Jurimetri, Ghalia, Jakarta.

\section{Laws and regulations}

[1] Criminal Procedure Code

[2] Act No. 2 of 2002 On the Indonesian National Police.

[3] Act No. 22 of 2009 On Road Traffic and Transportation.

[4] Regulation of the Head of the Indonesian National Police Number 15 of 2013 On Procedures for Handling Traffic Accidents

Etc

[1] Abdullah Khusairi, "Membangun Citra Positif Polri (Sebuah Strategi Menguasai Media Massa \& Media Sosial)", Paper in Limited Discussion with the Head of Public Relations of West Sumatra Regional Police, January 2016, (https://www.academia.edu, accessed November 20, 2019).

[2] Biar Polisi Lalu Lintas Blora Tak Pungli maka Dikenalkan e-tilang, (https://www.murianews.com, accessed November 20, 2019). 